\title{
Report on the August 2012 Brawley Earthquake Swarm in Imperial Valley, Southern California
}

\section{by Egill Hauksson, Joann Stock, Roger Bilham, Maren Boese, Xiaowei Chen, Eric J. Fielding, John Galetzka, Kenneth W. Hudnut, Kate Hutton, Lucile M. Jones, Hiroo Kanamori, Peter M. Shearer, Jamie Steidl, Jerry Treiman, Shengji Wei, and Wenzheng Yang}

Online Material: Tabulation of parameters of the finite source model for the $M_{\mathrm{w}} 5.4$ earthquake; tabulation of stress drops, including the event ID and other earthquake parameters.

\section{INTRODUCTION}

The 2012 Brawley earthquake swarm occurred in the Brawley Seismic Zone (BSZ) within the Imperial Valley of southern California (Fig. 1). The BSZ is the northernmost extensional segment of the Pacific-North America plate boundary system. Johnson and Hill (1982) used the distribution of seismicity since the 1930s to outline the geographical extent of the BSZ, defining boundaries of the BSZ as shown in Figure 1. Its north-south extent ranges from the northern section of the Imperial fault, starting approximately $10 \mathrm{~km}$ north of the United States-Mexico international border and connecting to the southern end of the San Andreas fault, where it terminates in the Salton Sea. Larsen and Reilinger (1991), who defined a similar geographical extent of the BSZ, argued that the BSZ was migrating to the northwest, which they associated with the propagation of the Gulf of California rift system into the North American continent.

During the seismically active period of the 1970s, the BSZ produced close to half of the earthquakes recorded in California (Johnson and Hill, 1982; Hutton et al., 2010). However, for two decades following the 1979 Imperial Valley mainshock $M_{\mathrm{w}} 6.4$ and its aftershock sequence, the BSZ was much less active. In general, the BSZ seismicity is indicative of right-lateral strike-slip plate motion accompanied by crustal thinning as well as possible associated fluid movements in the crust (Chen and Shearer, 2011).

The 2012 Brawley swarm produced more than 600 events recorded by the United States Geological Survey (USGS)California Institute of Technology (Caltech) Southern California Seismic Network (SCSN). Other monitoring instruments in the region, such as the Global Positioning System (GPS) network, creepmeters, and the Wildlife Liquefaction Array (WLA) also recorded signals from the largest events. In addition, Interferometric Synthetic Aperture Radar (InSAR) satellites collected images from space.

\section{THE 2012 BRAWLEY SWARM}

The 2012 Brawley swarm started near the town of Brawley at 4:30 (UTC) on 26 August, with three events of $M_{\mathrm{w}}>5$ occurring within $5 \mathrm{~min}$. The seismic activity picked up again at 11:43 (UTC) and continued at a steady rate. The three largest earthquakes $\left(M_{\mathrm{w}} 5.3, M_{\mathrm{w}} 4.9\right.$, and $\left.M_{\mathrm{w}} 5.4\right)$ in the sequence occurred over a period of $90 \mathrm{~min}$, starting at 19:31 (UTC). The largest $\left(M_{\mathrm{w}} 5.4\right)$ earthquake was widely felt across southernmost California, northern Baja California, and western Arizona. The SCSN ShakeMap showed strong to very strong shaking within a $10-\mathrm{km}$ distance of the epicenter (http:// www.cisn.org).

The causative fault of the 2012 swarm had not been previously mapped. Nonetheless, surface fractures that are related to the swarm were identified both from InSAR images and field observations. Prior occurrences of surface faulting in association with swarm activity within the BSZ activity include the 2005 swarm (Lohman and McGuire, 2007; Rymer et al., 2011). The largest event of the 2005 swarm was $M_{\mathrm{w}} 5.1$, yet surface rupture was up to $20 \mathrm{~cm}$ in that case. Similarly, the 2006 Cerro Prieto swarm with the largest event of $M_{\mathrm{w}} 5.4$ had surface rupture along the Morelia fault of $20-30 \mathrm{~cm}$ (SuárezVidal et al., 2007). Also, just to the west of the BSZ, the Elmore Ranch event $M_{\mathrm{S}} 6.2$ of the 1987 Superstition Hills sequence involved extensive surface rupture on a zone of cross-faults (e.g., Hudnut et al., 1989; Sharp et al., 1989).

In this report, we summarize the recent data and interpretations for this sequence. In particular, we highlight efforts to (1) find the surface rupture; (2) develop a finite source modeling using both seismic and GPS waveforms, together with (3) data from creepmeters; and (4) a liquefaction array. The temporal and spatial evolution and focal depths of the events are very important for understanding the crustal deformation processes that cause such swarms. 


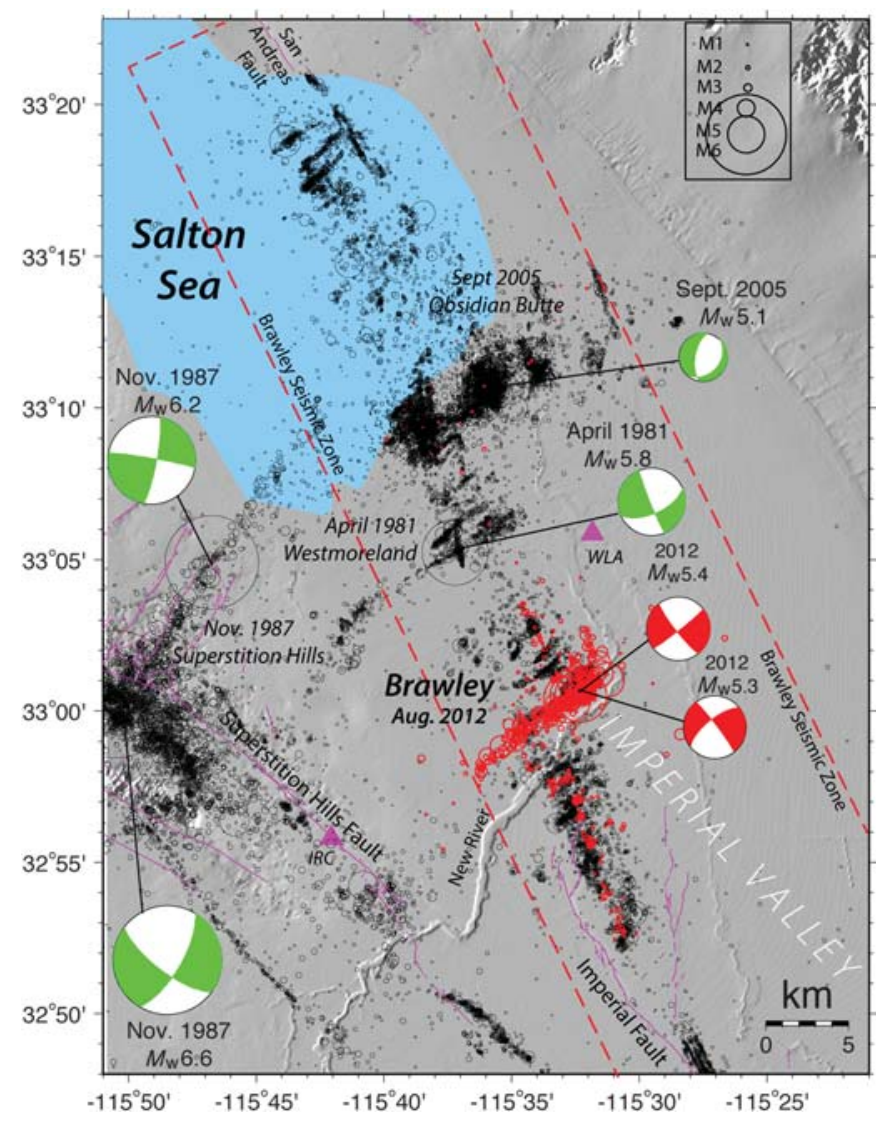

A Figure 1. The seismicity from 1981 to 2012 August is shown as black open circles, and the events of the 2012 August Brawley swarm are shown as red circles. Lower-hemisphere focal mechanisms of the $M_{\mathrm{w}}>5$ events are shown. IRC, Imler Road creepmeter; WLA, Wildlife Liquefaction Array. The east and west boundaries of the BSZ as defined by Johnson and Hill (1982) are shown as red dashed lines. Late Quaternary fault traces (magenta) from Jennings and Bryant (2010) are also shown.

\section{MAINSHOCK MOMENT TENSOR}

The SCSN automated analysis of waveforms determined the first version of the real-time SCSN moment tensor. Clinton et al. (2006) described the implementation of the method that was initially developed by Dreger and Helmberger (1993). Subsequently, several other moment tensors were created, which are listed in Table 1.

Moment tensors provide the depth of the centroid of moment release, whereas the $P$ - and $S$-arrival times provide the hypocenter depth or the depth of rupture initiation, often different from the depth of the centroid. In the regional solutions, the minimum misfits between real and synthetic waveforms constrain the centroid depth at $\sim 5 \mathrm{~km}$ and the $M_{\mathrm{w}}$ at 5.5. The teleseismic centroids tend to be deeper, in part, because the depth resolution is less. Chu and Helmberger (2013) also determined a regional double-couple solution using the "cut-and-paste" method (Zhu and Helmberger, 1996) as well as a local velocity model appropriate for the Imperial Valley basin. They found that using a local velocity model, they needed a depth of $\sim 4 \mathrm{~km}$ for the centroid. In comparison, the hypocentral depth of the mainshock from the $P$ - and $S$-arrival times is $6.9 \mathrm{~km}$, located near the bottom of the finite slip distribution.

A new regional $W$-phase inversion method, based on the teleseismic approach of Kanamori and Rivera (2008), using 34 broadband components of SCSN stations with passband of 50-150 s, yielded a similar mechanism as the SCSN real-time method. For the regional $W$-phase method, Green's functions were generated using the frequency wave number $(\mathrm{FK})$ technique (Zhu and Rivera, 2002) and a 1D southern California velocity model (Zhao and Helmberger, 1994). The teleseismic $W$-phase and Centroid Moment Tensor solutions, which represent long-period properties of the source, provided an accurate moment tensor but poorly constrained centroid depths in the range of $12 \mathrm{~km}$ (see also http://earthquake

Table 1

Preferred Nodal Plane for the Largest $\left(M_{w}\right.$ 5.4) Earthquake in the Swarm

\begin{tabular}{|lcccrl|}
\hline $\boldsymbol{M}_{\mathbf{w}}$ & $\begin{array}{c}\text { Centroid } \\
\text { Depth (km) }\end{array}$ & Strike & Dip & Rake & \multicolumn{1}{c|}{ Source/Method } \\
\hline 5.44 & 5.0 & $233^{\circ}$ & $66^{\circ} \mathrm{NW}^{*}$ & $-22^{\circ}$ & SCSN $^{\dagger}$ (Dreger and Helmberger, 1993) \\
5.48 & 11.5 & $238^{\circ}$ & $74^{\circ} \mathrm{NW}$ & $-11^{\circ}$ & $W$-phase regional \\
5.5 & 11.0 & $228^{\circ}$ & $74^{\circ} \mathrm{NW}$ & $-45^{\circ}$ & USGS teleseismic $W$ phase \\
5.4 & 12.0 & $232^{\circ}$ & $67^{\circ} \mathrm{NW}$ & $-12^{\circ}$ & Global CMT \\
5.44 & $6.9^{\ddagger}$ & $227^{\circ}$ & $82^{\circ} \mathrm{SE}$ & $6^{\circ}$ & Focal mechanism from first motions and $S / P$ ratios \\
5.4 & 5.5 & $238^{\circ}$ & $87^{\circ} \mathrm{NW}$ & $-7^{\circ}$ & Regional cut-and-paste method (Chu and Helmberger, 2013) \\
5.4 & 4.0 & $239^{\circ}$ & $90^{\circ}$ & $1^{\circ}$ & Teleseismic cut-and-paste method (Chu and Helmberger, 2013) \\
\hline
\end{tabular}

${ }^{*} N W$, dips to the northwest; SE, dips to the southeast.

†SCSN, Southern California Seismic Network; USGS, United States Geological Survey; CMT, Centroid Moment Tensor.

${ }^{\ddagger}$ Hypocentral depth from arrival times. 
.usgs.gov/earthquakes/eqarchives/fm/ci15200401_wmt.php and http://www.globalcmt.org/CMTsearch.html).

In general, all of the moment tensors and the first-motion mechanisms exhibited similar strike-slip motion with a minor normal component on a steeply dipping southwest-striking nodal plane. This plane coincided with the trend of the main aftershock distribution. The agreement between the moment tensor solutions, including teleseismic and regional approaches, suggests that the rupture had an ordinary duration for its seismic moment. However, the differences in local velocity structure used by each method involve trade-offs between dip and rake, resulting in slightly different parameters. The values of all of these parameters are within the expected range of uncertainty.

\section{SURFACE RUPTURE OR FRACTURES}

We calculated and interpreted InSAR interferograms at X-band $(31 \mathrm{~mm})$ wavelength from TerraSAR-X (German Aerospace Center-DLR) using the Jet Propulsion LaboratoryCaltech ROI_pac software (Rosen et al., 2004). Two interferograms cover the periods from 9 to 31 August 2012 on the ascending track (Fig. 2) and 12 August to 3 September 2012 on the descending track. In the field, we conducted a precisely guided reconnaissance inspection based on the InSAR phase discontinuities to locate, identify, and document surface fractures in the epicentral area. The areas inspected lay to the west, southwest, and south of the principal northeast-trending earthquake swarm. We identified surface rupture in two locales, one in the epicentral area and the other along the northernmost Imperial fault.

Fractures of tectonic origin were identified with certainty, despite a lack of measurable offset, at the southwest end of the Brawley swarm seismicity lineament (from SCSN locations from USGS-Caltech; Fig. 1), at a location approximately $4 \mathrm{~km}$ west of the City of Brawley near the intersection of Roberts Road and W. Deotsch Road (locality D in Fig. 2b).

Many other locations with notable but small $(<0.5 \mathrm{~cm})$ offsets in the InSAR were also checked in the epicentral region, but only a few questionable fractures, not necessarily tectonic in origin, were found at these localities (localities A-J in Fig. 2b).

The surface rupture at locality D (Fig. 2a) was observed crossing an agricultural field and consisted of a zone of discontinuous fractures with a suggestion of a right-stepping relationship. The two largest fracture sets, each over $100 \mathrm{~m}$ long, were offset en echelon, stepping to the right. Displacement, however, was small and could not be measured. The field had been plowed prior to the rupture and had also been moistened at least once in recent weeks by rainfall. The fractures

(a)

(b)

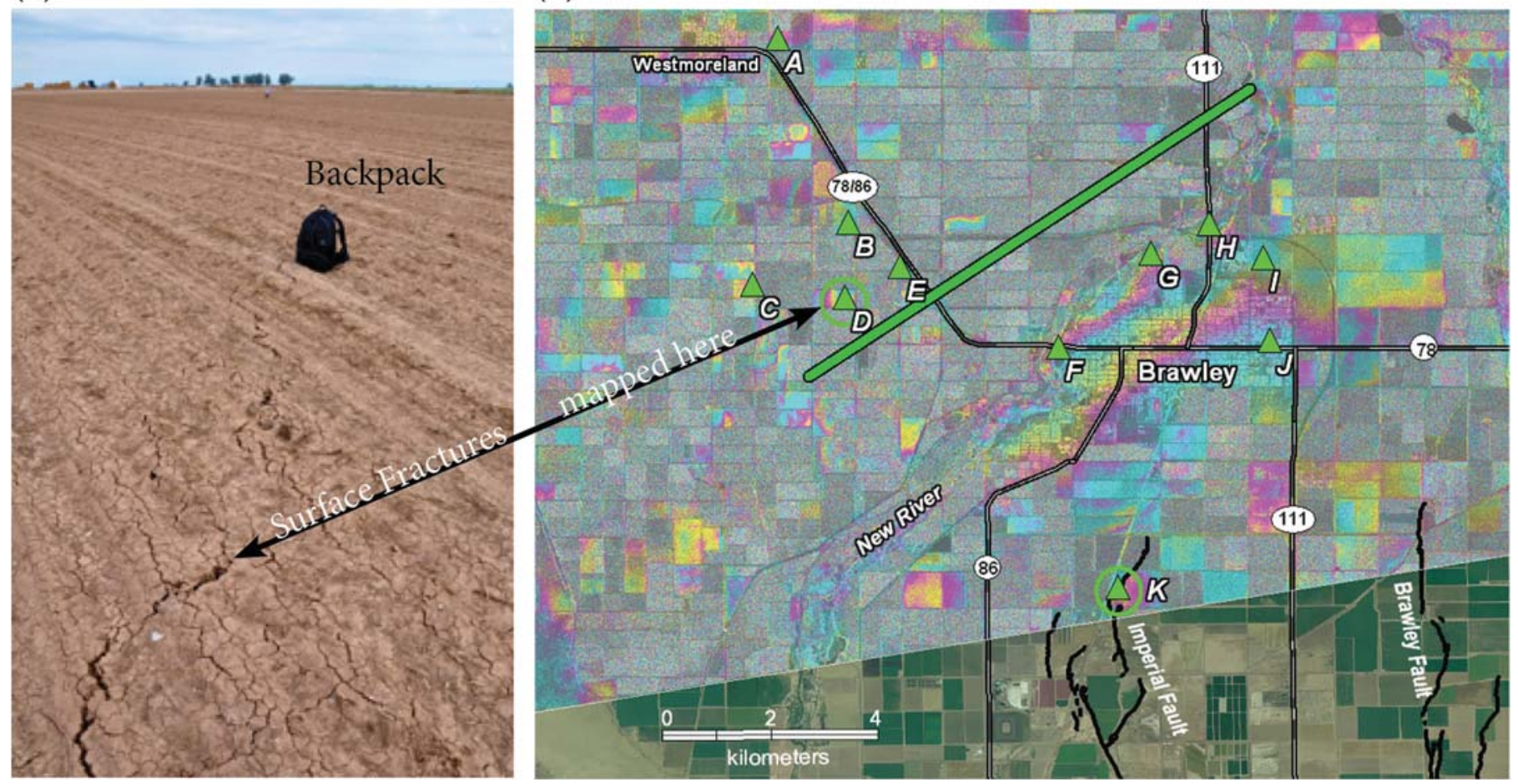

$\Delta$ Figure 2. (a) Surface rupture at locality D, showing the zone of fracturing as described in the accompanying text. View toward the northeast from the middle of the breaks. Small backpack for scale and photo by K. Hudnut. (b) Localities (A-K) field checked on 10 September 2012 in the epicentral area of the Brawley swarm of August 2012 on TerraSAR-X (09-31 August 2012) interferogram. Original TerraSAR-X data copyright 2012 DLR. In the background, the map shows the agricultural fields, major roads, and the New River drainage. Fractures were observed at locations $\mathrm{D}$ and $\mathrm{K}$. The green solid line is the approximate location of the finite fault model for the largest event $\left(M_{\mathrm{w}} 5.4\right)$ in the sequence. 
were evident as a $\mathrm{N} 45^{\circ} \mathrm{E}$-trending zone of wider fractures overprinted on a relatively consistent pattern of dessication cracks along the north-south furrows. The TerraSAR-X interferograms indicate as much as $3 \mathrm{~cm}$ of offset across the zone in this field. It is not possible to tell if the surface displacement occurred as a coseismic slip or afterslip because the field observations were delayed (10 September 2012).

The second rupture we observed was along the trace of the Imperial fault, north of Carey Road (locality $\mathrm{K}$ in Fig. 2b). Again, the ground had been moistened by recent rains, but we were able to observe two localized zones, extending for a total of approximately $20-30 \mathrm{~m}$, of linear discontinuous fractures overprinted by the dessication polygons. We judge this to represent triggered slip along this fault trace. The interferograms suggest around $1 \mathrm{~cm}$ of slip at this location.

\section{FINITE FAULT MODEL}

We determined a finite slip model for the $M_{\mathrm{w}} 5.4$ (event ID 15200401) earthquake by joint inversion of nearby strongmotion and high-rate GPS data, using a simulated annealing algorithm (Ji et al., 2002). We select a rupture plane with strike of $239^{\circ}$ and dip of $90^{\circ}$ that has similar strike and dip as the trend of the swarm hypocenters and the first-motion $S / P$-ratio focal mechanism. The slip model is well constrained both in lateral extent and depth by the nearby strong-motion and GPS data (Fig. 3). The 1D velocity model used in this inversion was derived by waveform modeling of a smaller $M_{\mathrm{w}} 4.0$ earthquake that occurred near the hypocenter of the $M_{\mathrm{w}} 5.4$ event (S. Wei et al., unpublished manuscript, 2013).

Most of the slip is distributed in the depth range from 3 to $6 \mathrm{~km}$ and extends approximately $6 \mathrm{~km}$ along strike, with a maximum slip amplitude of approximately $0.4 \mathrm{~m}$. The slip model reveals clear unilateral rupture directivity and two asperities, with the first one above the hypocenter and the second approximately $3 \mathrm{~km}$ to the southwest along the strike.(E) Table S1 (available as an electronic supplement to this paper) provides finite fault model parameters.

\section{RELOCATIONS OF HYPOCENTERS}

We relocated the swarm using a $3 \mathrm{D}$ velocity model (Hauksson, 2000) and HypoDD (Waldhauser and Ellsworth, 2000). Prior to inversion, we adjusted the starting $P$-wave velocity model in

(a)

(b)

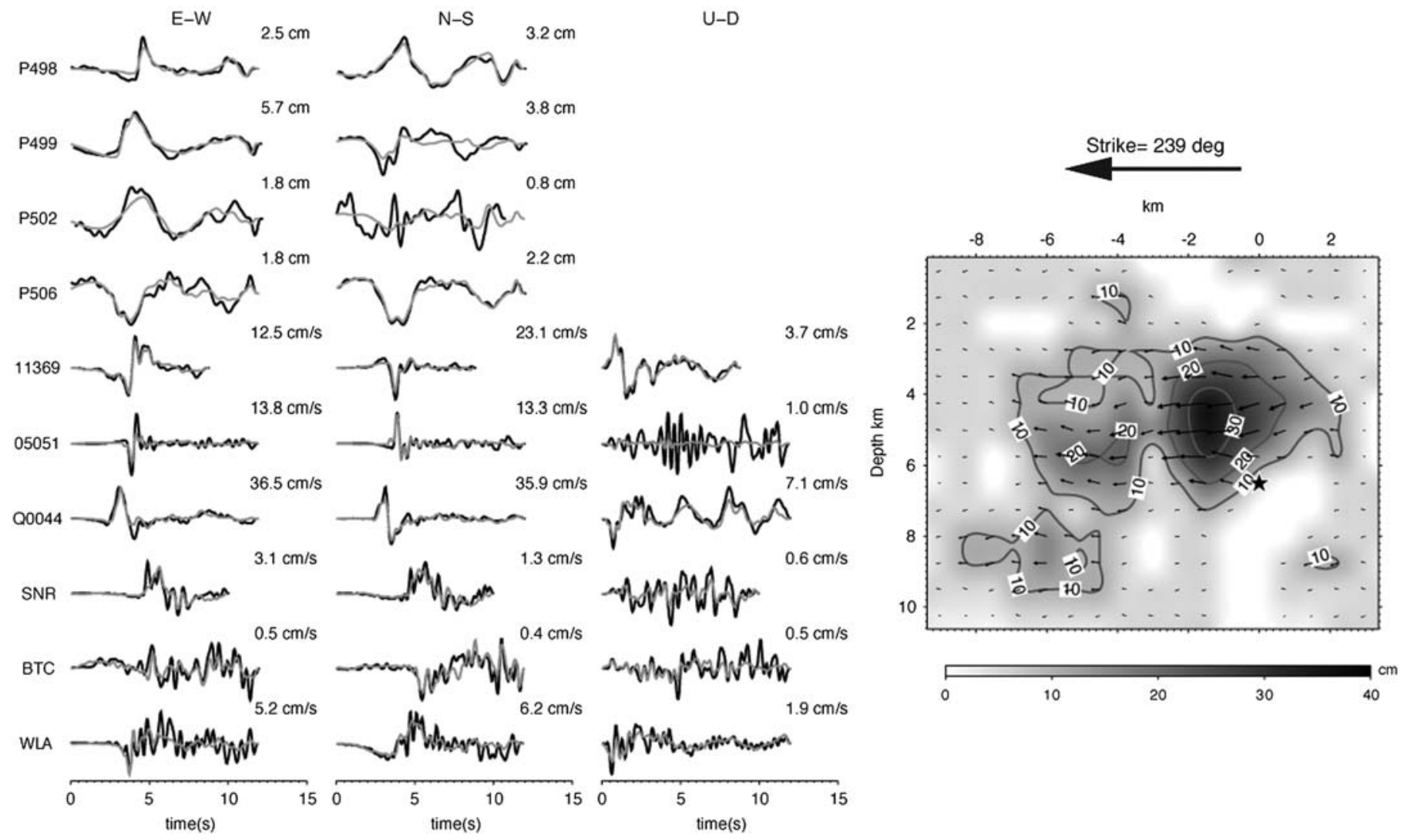

$\Delta$ Figure 3. (a) The GPS high-sample-rate waveforms (UNAVCO GPS stations, P498, P499, P502, and P506) and strong-motion records from the CISN. The waveforms are shown as black, whereas the synthetic waveforms are shown as gray. Both data and synthetics are filtered to $0.1-2.0 \mathrm{~Hz}$. (b) Finite slip model for the $M_{\mathrm{w}} 5.4$ (15200401) earthquake showing contours of slip amplitude, with arrows indicating slip direction. The epicenter is shown as the black star, and the slip amplitude is proportional to the arrow size and indicated by the grayscale bar. 
the Imperial Valley basin to be approximately $2.5 \mathrm{~km} / \mathrm{s}$ at $1 \mathrm{~km}$ depth to account for the low $V_{P}$ velocities in basin sediments (Han et al., 2012). This 3D model can be used to determine accurate hypocenters because the azimuthal distribution of stations is fairly complete, but the model needs to be further refined before it can be used for tectonic interpretation. The relocations reveal a narrow $10-\mathrm{km}$-long, linear southwest seismicity trend concentrated in the depth range of 4-9 km (Fig. 4). This trend is aligned along the southwest-striking nodal plane of the mainshock moment tensors and extends mostly to the southwest away from the mainshock.

The distribution of focal depths for the swarm earthquakes is consistent with the finite source model. The events surround the two high-slip asperities, with more seismicity near the bottom of the large-slip asperity and on the northeast side and less seismicity near the base of the smaller low-slip asperity located $3 \mathrm{~km}$ to the southwest. Furthermore, the three largest events of $M_{\mathrm{w}} 5.5, M_{\mathrm{w}} 5.3$, and $M_{\mathrm{w}} 4.9$ are located within approximately $1 \mathrm{~km}$ of each other with focal depths of 6.9, 5.7, and $5.2 \mathrm{~km}$, respectively. These focal depths are fairly shallow, but they are typical for this region (Hauksson et al., 2012). The uncertainties in the depth determinations are small $(\sim 0.7 \mathrm{~km})$ because of the dense distribution of seismic stations in the region.

The two depth cross sections show the details of the depth distribution of the earthquakes in the swarm, as well as the $V_{P}$ velocities in the swarm area. The tight distribution of earth-

(a)

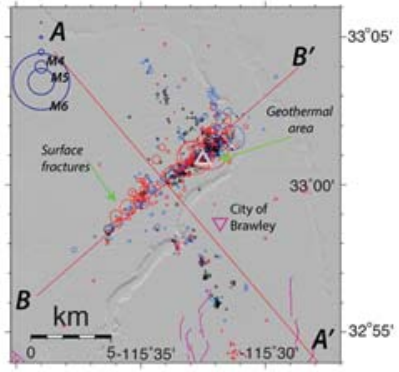

(c)

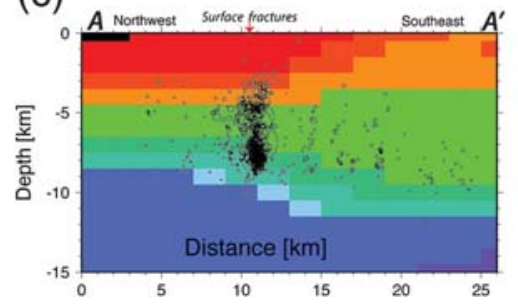

A Figure 4. (a) Relocated seismicity, in which the dates of the events are indicated by the color of the circles. Location of surface rupture or fractures as a white and red line, geothermal area as a triangle, and town of Brawley as inverted triangle are indicated. The mapped surface rupture and the Brawley geothermal areas are also shown. Late Quaternary faults are shown in color cyan. The 3D V P model is modified from Hauksson (2000). (b) Northeast depth cross section. (c) Northwest cross section. quakes in the $A-A^{\prime}$ cross section shows that probably the bulk of the swarm events occurred on only one vertical fault. The seismicity distribution in the $B-B^{\prime}$ cross section suggests the presence of two clusters along this southwest-striking plane, separated by less than $2 \mathrm{~km}$. The $V_{P}$ velocities are low in the near surface, indicating that the basin sediments bottom at approximately $4-5 \mathrm{~km}$ depth. The sediments consist of unconsolidated clastic sediment from the Colorado River. The basement, below the sediments, is interpreted to be metamorphosed Colorado River sediments, which have been metamorphosed by the high geotherm (Fuis et al., 1984). The $V_{P}$ of the basement is lower than that for the average southern California basement because it is more felsic or fractured. The lower crust, as characterized by $V_{P}$ greater than $6.7 \mathrm{~km} / \mathrm{s}$, can be seen at a depth of $12 \mathrm{~km}$ in the northeast corner of the $B-B^{\prime}$ cross section (Fuis et al., 1984; Han et al., 2012). Improved resolution of the $3 \mathrm{D}$ complexity in the $V_{P}$ structure is expected when the results of the analysis of the data collected during the Salton Seismic Imaging Project (SSIP) experiment become available (Han et al., 2012; Rose et al., 2012).

Some off-fault seismicity occurred along an almost northsouth strike, extending $10 \mathrm{~km}$ away to the south of the main rupture and $10 \mathrm{~km}$ to the north of the rupture, en echelon offset across the rupture (Fig. 1). This seismicity occurred within regions that have been seismically active during the last 30 years.

\section{FOCAL MECHANISMS}

We used first-motion polarities and $S / P$ amplitude ratios and the HASH method of Hardebeck and Shearer $(2002,2003)$, as implemented by, to determine focal mechanisms for the events in this swarm. There are 13 events of $M_{\mathrm{w}} \geq 3.5$ that have A- or B-quality focal mechanisms (Fig. 5). The focal mechanisms of the large earthquakes in the sequence are similar to the corresponding moment tensor mechanisms for the largest event (Table 1). The focal mechanisms of most of the events predominantly exhibit strike-slip motion on northeast- or northwest-striking nodal planes. Overall, the focal mechanisms uniformly suggest the presence of a coherent regional stress field.

Along the almost north-south trend of seismicity, normal faulting is more prominent on either north or north-northeaststriking nodal planes than along the main northeast-trending aftershock zone. Among the five events of $M_{\mathrm{w}} \geq 2.0$ that have A-quality focal mechanisms (Fig. 5), three of them exhibit normal faulting in north- or north-northeast-striking nodal planes. The current plate boundary right-lateral strike-slip motion, in combination with crustal extension and thinning, causes seismicity with left-lateral faulting as well as small-scale normal faulting on north- to north-northeast-striking nodal planes.

\section{EARTHOUAKE STATISTICS}

This sequence of earthquakes is described as a swarm because it started with a series of small earthquakes, grew in number and 


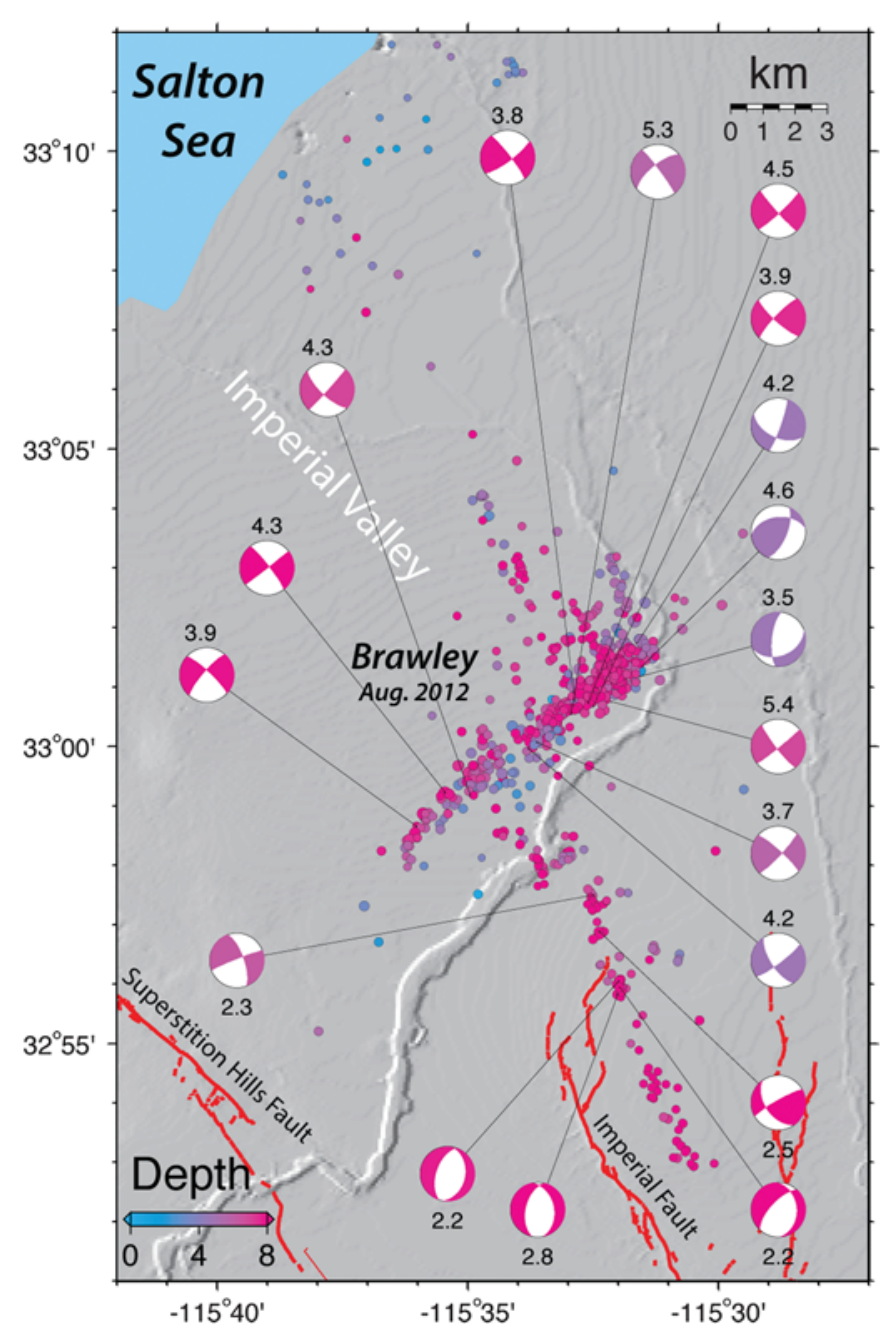

$\Delta$ Figure 5. Selected first-motion and $S / P$-ratio lowerhemisphere focal mechanisms for the 2012 Brawley sequence. Each event is labeled with its magnitude, and the color bar indicates focal depths in $\mathrm{km}$.

magnitude over the first $5.5 \mathrm{hr}$, and had three events close to the largest magnitude.

Following the largest event of $M_{\mathrm{w}} 5.4$, the swarm decayed as described by the classic modified Omori law $(R(t)=$ $\left.K(t+c)^{-p}\right)$ (Utsu, 1961), in which $R(t)$ is the earthquake rate; $t$ is time since the mainshock; and $K, c$, and $p$ are constants (Fig. 6). The $K$-value measured in terms of $M_{\mathrm{w}} \geq 1.8$ aftershocks/day was 55.4 , with a $98 \%$ range of \pm 3.5 . This $K$ value corresponds to the $a$-value of Reasenberg and Jones (1989) of -0.94 , which is high compared with the California average of -1.8 .

The mean $p$-value for Californian aftershocks is 1.08 (Reasenberg and Jones, 1989). However, Kisslinger and Jones (1991) showed that the $p$-values for sequences in the high-heatflow area of the Salton Trough are higher, up to 1.7, than elsewhere on average in southern California. Thus, the $p$-value of 1.2 for the Brawley swarm indicates a decay rate faster than the sequences located elsewhere in southern California but similar to other earthquake sequences in the Salton Trough region.
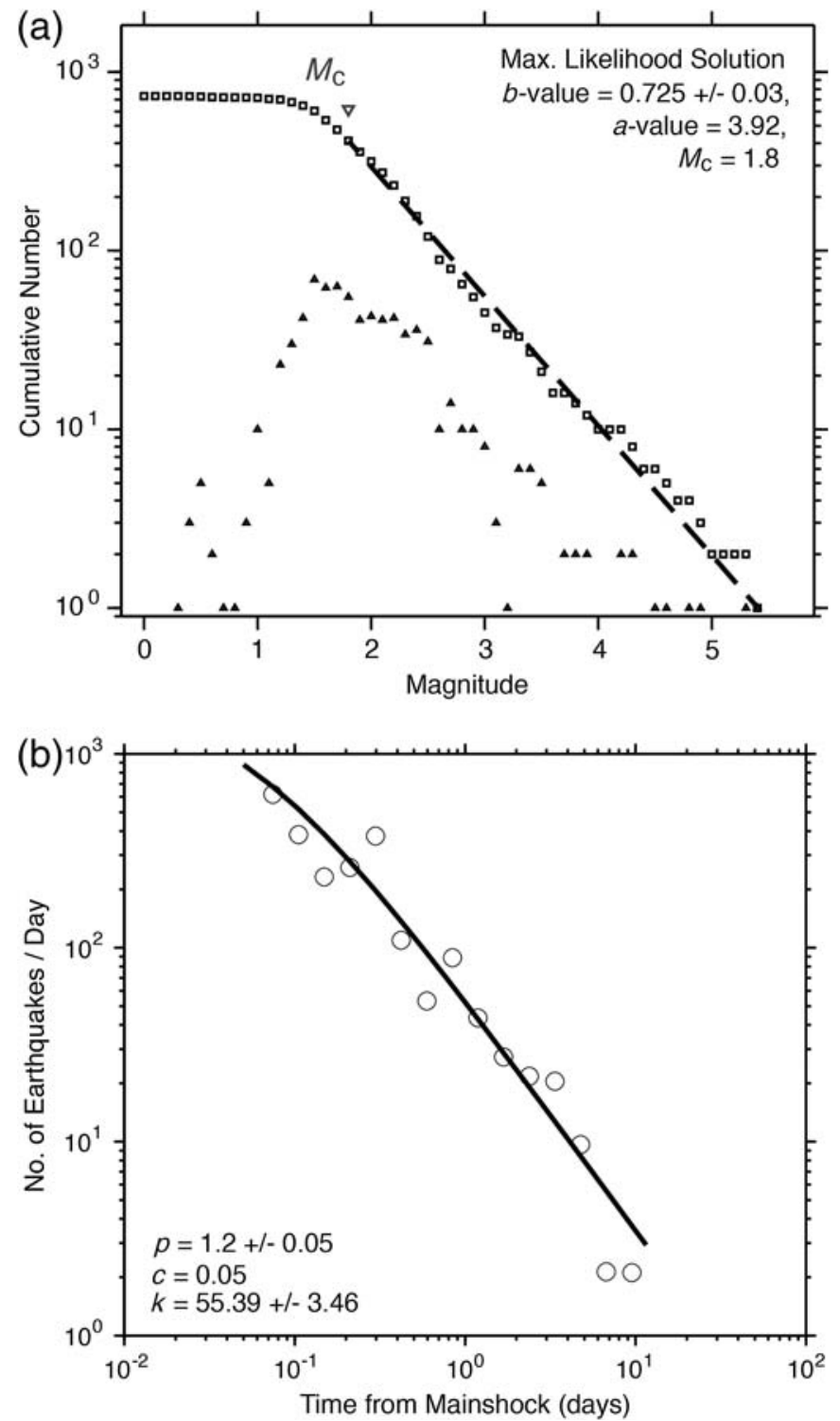

A Figure 6. (a) Cumulative and binned number of earthquakes versus magnitude. (b) Number of earthquakes per day versus time from mainshock. Zmap software was used to make these plots (Wiemer, 2001).

This rapid decay rate means that the sequence would be expected to terminate relatively quickly. This decay rate would predict only five earthquakes of $M_{\mathrm{w}} 1.8$ or greater in the last 3 weeks of September. However, the last event in the sequence was recorded 10 September. If some of this seismic activity is related to geothermal activity, a different driving force could change the expected temporal pattern, but the observed pattern is close to the expected level of variability between swarms of tectonic origin (Johnson and Hill, 1982).

The $b$-value is 0.725 , which is significantly smaller than the average $b$-value of 1.0 for all of southern California (Hutton et al., 2010). With a one-sigma error of 0.03 and over 600 events above the completeness threshold, this low $b$-value should not be an artifact of incomplete data. The low $b$-value suggests a deficit 
of smaller earthquakes, which is sometimes interpreted as aboveaverage crustal stress conditions (Scholz, 1968).

Overall, the magnitude-frequency statistics are similar to those Kisslinger and Jones (1991) reported for previous sequences in Imperial Valley. However, they differ from those we have observed for some other active geothermal areas such as Coso in eastern California, in which the $b$-value is $\sim 1.25$.

\section{SPATIAL AND TEMPORAL EVOLUTION}

A weighted-least-square method is applied to model the spatial-temporal migration behavior of this swarm based on the relocated earthquake hypocenters in the depth range from 4 to $8 \mathrm{~km}$. This weighting approach accounts for the upper triangular nature of the time-versus-distance behavior by applying the L1 norm only within a $0.5-\mathrm{hr}$ window and penalizing earlier events more than the late events outside of this window (further details of the method are provided by Chen and Shearer, 2011, appendix A).

The seismicity before the first $M_{\mathrm{w}}>5$ earthquake migrated bilaterally along an azimuth of approximately $55^{\circ}$ (approximately northeast-southwest) at a velocity of approximately $0.5 \mathrm{~km} / \mathrm{hr}$ (Fig. 7). The first three events (which occurred at 4:30 UTC) that were significantly separated in time from the main sequence (approximately $8 \mathrm{hr}$ later) did not show migration and were not included in the velocity calculation. The southwest migration stopped after the first $M_{\mathrm{w}}>5$ earthquake, but the northeast migration continued until the second $M_{\mathrm{w}}>5$ earthquake.
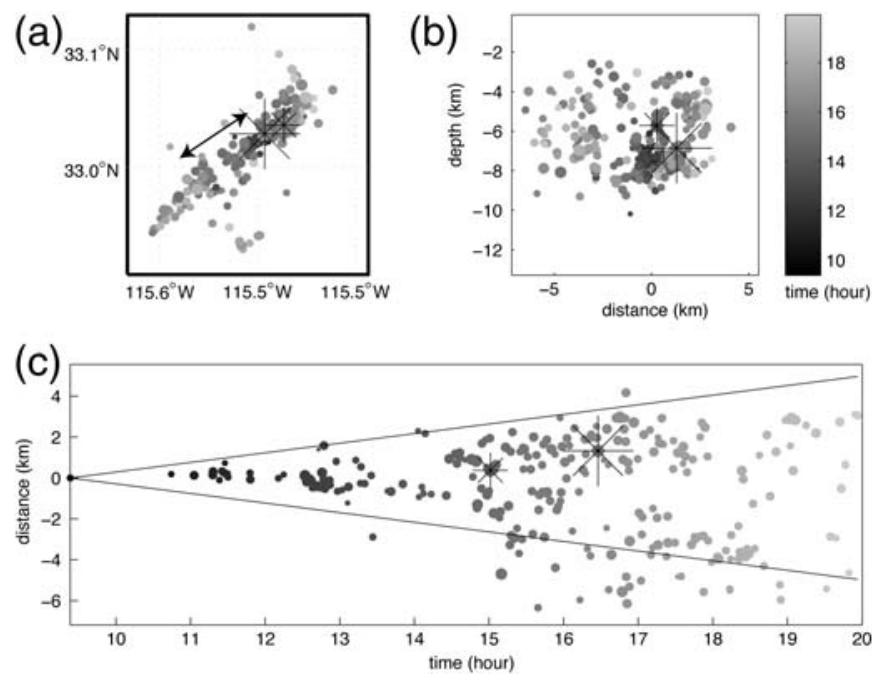

A Figure 7. (a) Epicenters shaded in gray by time of occurrence. Arrow indicates the bilateral migration direction, away from the first hypocenter in the sequence. (b) Depth versus distance along the bilateral migration direction from the first hypocenter. (c) The spatial and temporal migration of the hypocenters. The smaller black star is the first $M_{\mathrm{w}}>5$ event $\left(M_{\mathrm{w}} 5.3\right)$; the larger star is the second $M_{\mathrm{w}}>5$ event $\left(M_{\mathrm{w}}\right.$ 5.4). In all three figures, events are shaded in gray by time as indicated in the gray scale bar.
Four smaller swarms before 2009 (1983, 1986, 1999, and 2008) occurred in the same region (Chen and Shearer, 2011). The most recent one in 2008 had a roughly similar migration velocity of $0.3 \mathrm{~km} / \mathrm{hr}$. Each of these swarms exhibited either bilateral or unilateral migration directions, with three swarms having unilateral southwestward migration.

Estimated stress drops for the 2012 swarm earthquakes show a fair amount of scatter, ranging from 0.05 to $1.4 \mathrm{MPa}$ following a log-normal distribution. The stress drops are computed using the method described in Shearer et al. (2006), in which an empirical Green's function (EGF) is obtained by fitting a Brune-type source model to binned source spectra at 0.2-magnitude intervals. When EGFs are computed for subsets of the data using temporal or spatial binning, the stress drop estimates exhibit some degree of instability in their median values and also with different magnitude bin ranges. The origin of these instabilities warrants further study. However, when all events from 1981 to 2012 are included, the results are consistent and stable, with a median value of $0.25 \mathrm{MPa}$, agreeing with the values obtained in Chen and Shearer (2011). (E) Table S2 (see electronic supplement) provides the tabulation of stress drops.

\section{PREVIOUS SEISMICITY}

During the past 80 years of SCSN earthquake monitoring, the BSZ has been known for its high rate of both mainshockaftershock and swarm sequences (Johnson and Hutton, 1982; Hutton et al., 2010). During the 1970s, the whole length of the BSZ was dominated by swarm activity. The largest recent mainshock to occur in the BSZ was the $M_{\mathrm{w}} 6.41979$ Imperial Valley mainshock, which had an epicenter just south of the MexicoUnited States international border and extended to $33.03^{\circ}$ in the north (Johnson and Hill, 1982). In late 1979, a cluster of aftershocks, with the largest event of $M_{\mathrm{w}} 5.8$, occurred within the region of the 2012 swarm. The $M_{\mathrm{w}} 6.4$ mainshock was followed by an average aftershock sequence lasting only for a few years. During the period from 1986 to 1999 , seismic quiescence dominated the region. The quiescence was terminated by several swarms in late 1999 and early 2000 (Fig. 8).

The completeness of the SCSN catalog in the region improved with time as seismic stations were added to improve coverage (Hutton et al., 2010). A major improvement took place in 2008 when the SCSN began recording data from a dense network of stations around the south end of the Salton Sea.

The two seismicity clusters that begin forming in the late 1980s, at the south shore of the Salton Sea, are related to the geothermal areas. The production of geothermal energy started at that time and has resulted in steady seismicity in the region. The seismicity is expressed as two geographically separate distributions in Figure 8.

The April 1981 Westmoreland swarm occurred $15 \mathrm{~km}$ to the north-northwest of Brawley. It was characterized by a strike-slip-faulting mainshock of $M_{\mathrm{w}} 5.8$ followed by numerous aftershocks, forming a left-lateral northeast trend. The 2005 Obsidian Butte sequence ruptured across the 


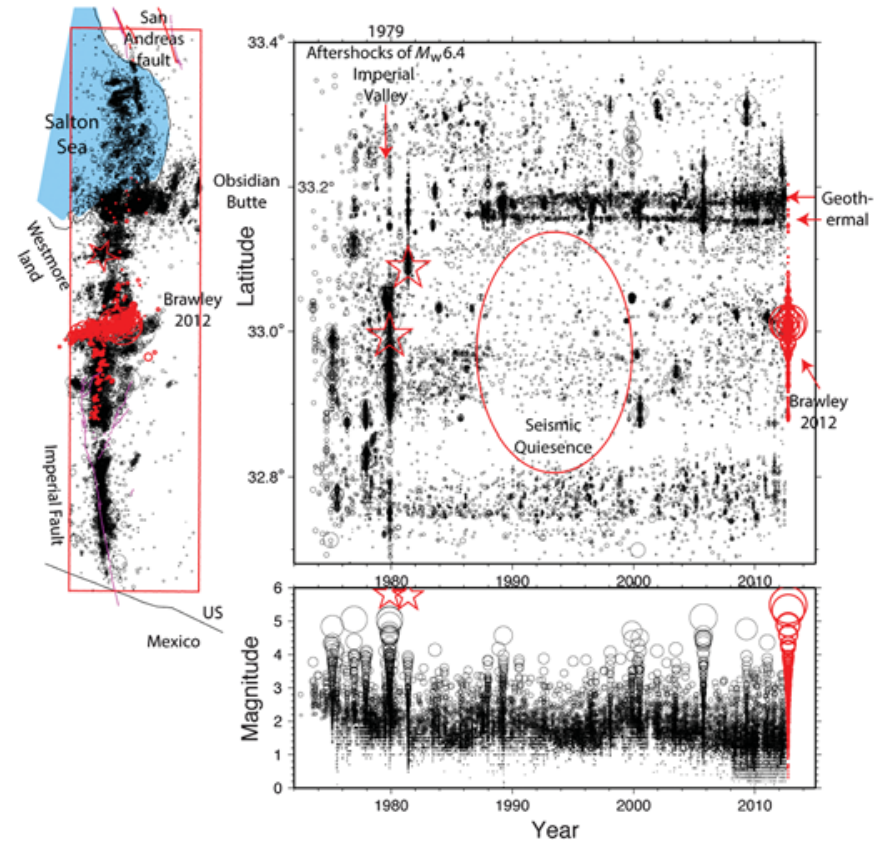

A Figure 8. Seismicity in the BSZ from 1970 to 2012. The 2012 Brawley swarm is shown as red circles. The seismic quiescence in late 1980s through the 1990s is indicated by a red ellipse. The temporal seismicity trends related to geothermal areas are marked with arrows.

geothermal fields near the southern end of the Salton Sea (Fig. 1). The sequence exhibited swarm-like behavior, and Lohman and McGuire (2007) attributed its migration pattern to a slow aseismic slip event at depth.

\section{MEASURED TRIGGERED SLIP}

Earthquakes on major faults in southern California frequently trigger minor amounts of surface slip on nearby and distant faults, especially those faults that between seismic events exhibit aseismic surface creep. Prior to the Brawley swarm in 2012, the $M_{\mathrm{w}} 7.2$ El Mayor-Cucapah earthquake of 2010 triggered slip on dozens of surface faults, some of which had not previously been mapped (Rymer et al., 2011). Although earthquakes in the BSZ have never before been observed to trigger slip on nearby faults, creepmeters can detect very small events of slip even when these are not evident in the field. In 2012, eight creepmeters were operating, four on the southern San Andreas fault, two on the northernmost splays of the Laguna Salada fault, one on the southernmost Imperial fault near the Mexican border, and one on the Superstition Hills fault. Each creepmeter has a least-count resolution of $\approx 12 \mu \mathrm{m}$ and a sampling rate of $30 \mathrm{~min}$ (Bilham et al., 2004). The records from these eight creepmeters indicate that triggered slip occurred only on the creepmeter crossing the Superstition Hills fault closest to the swarm (near Imler Road at $32.930^{\circ} \mathrm{N}, 115.701^{\circ} \mathrm{W}$ ), where it was manifest as two discrete events during the largest earthquakes in the swarm. The $M_{\mathrm{w}} 5.3$ earthquake at 19:31 UTC resulted in $98 \pm 12 \mu \mathrm{m}$ of slip, and the larger $M_{\mathrm{w}} 5.4$ earthquake at 20:57 UTC resulted in $49 \pm 12 \mu \mathrm{m}$ of slip (Fig. 9), a cumulative offset of $0.15 \pm 0.02 \mathrm{~mm}$. Our 30-min sampling rate does not permit us to judge the precise time the offset occurred, but in past events, it has typically accompanied the passage of surface waves (Bodin et al., 1994). This slip is too small to detect on the interferograms.

The fault slip events occurred $1 \mathrm{~min}$ after a data sample $\left(M_{\mathrm{w}} 5.3\right)$ and the $M_{\mathrm{w}} 5.4$ earthquake (with half the triggered slip) $3 \mathrm{~min}$ before a sample. No subsequent slip on the fault has occurred in the month following the swarm. Slip on the BSZ would place the creepmeter close to a node in the shear-strain field, suggesting that the slip triggering was not caused by almost instantaneous static strain but by dynamic shaking.

\section{STATIC STRESS CHANGE}

To explain the effects of the largest $\left(M_{\mathrm{w}} 5.4\right)$ earthquake in the Brawley sequence on nearby faults and off-fault triggered seismicity, we determine the static Coulomb stress changes using the approach of Lin and Stein (2004) and Toda et al. (2005). For the slip, we used a $15-\mathrm{cm}$ average slip from the finite source model over the mainshock fault plane as defined by aftershocks. This fault model extended for a distance of $6.8 \mathrm{~km}$ to the southwest and a distance of $3.2 \mathrm{~km}$ to the northeast from the $M_{\mathrm{w}} 5.4$ event hypocenter over a depth range of 3.0-7.0 km.

We assumed a regional stress direction of $\mathrm{N} 16^{\circ} \mathrm{E}$ (W. Yang and E. Hauksson, unpublished manuscript, 2013), a friction coefficient on receiver faults of 0.4 , Poisson's ratio of 0.25 ,

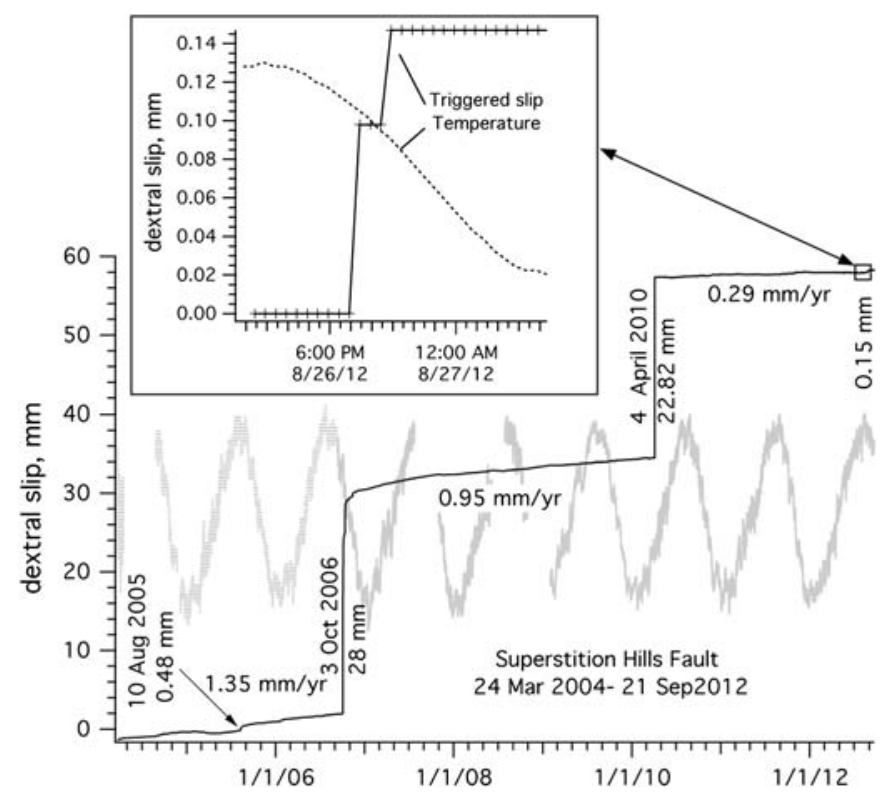

A Figure 9. Data from the graphite rod creepmeter on the Superstition Hills fault near Imler Road 2004-2012 (location IRC in Fig. 1). Dextral slip is indicated by the black line, and the gray line indicates temperature in the instrument vault. (inset top) Close-up view of slip triggered on the Superstition Hills fault (solid line) corrected for temperature (dotted line). Tick marks on trace indicate sampling interval. Total offset was $0.15 \mathrm{~mm}$. 
and an $8 \times 10^{5}$ bar Young's modulus. For the map view plots, we calculate the maximum Coulomb stress change at a depth of $6 \mathrm{~km}$. We resolve the Coulomb stress changes on optimally oriented strike-slip faults, which approximately follow the strike of the Superstition Hills fault.

The Coulomb model shows increases in shear-stress of $\sim 0.1$ to 1.0 bar across the north-south length extent of the BSZ, including the near-fault aftershocks and the northernmost segment of the Imperial fault. Numerous off-fault triggered earthquakes coincided with the stress increase within the BSZ. The Superstition Hills fault, to the west, experienced both stress increases and decreases (Fig. 10).

The seismicity formed scattered clusters within the BSZ and did not extend to other nearby faults such as the Superstition Hills fault. This suggests that small slip surfaces that

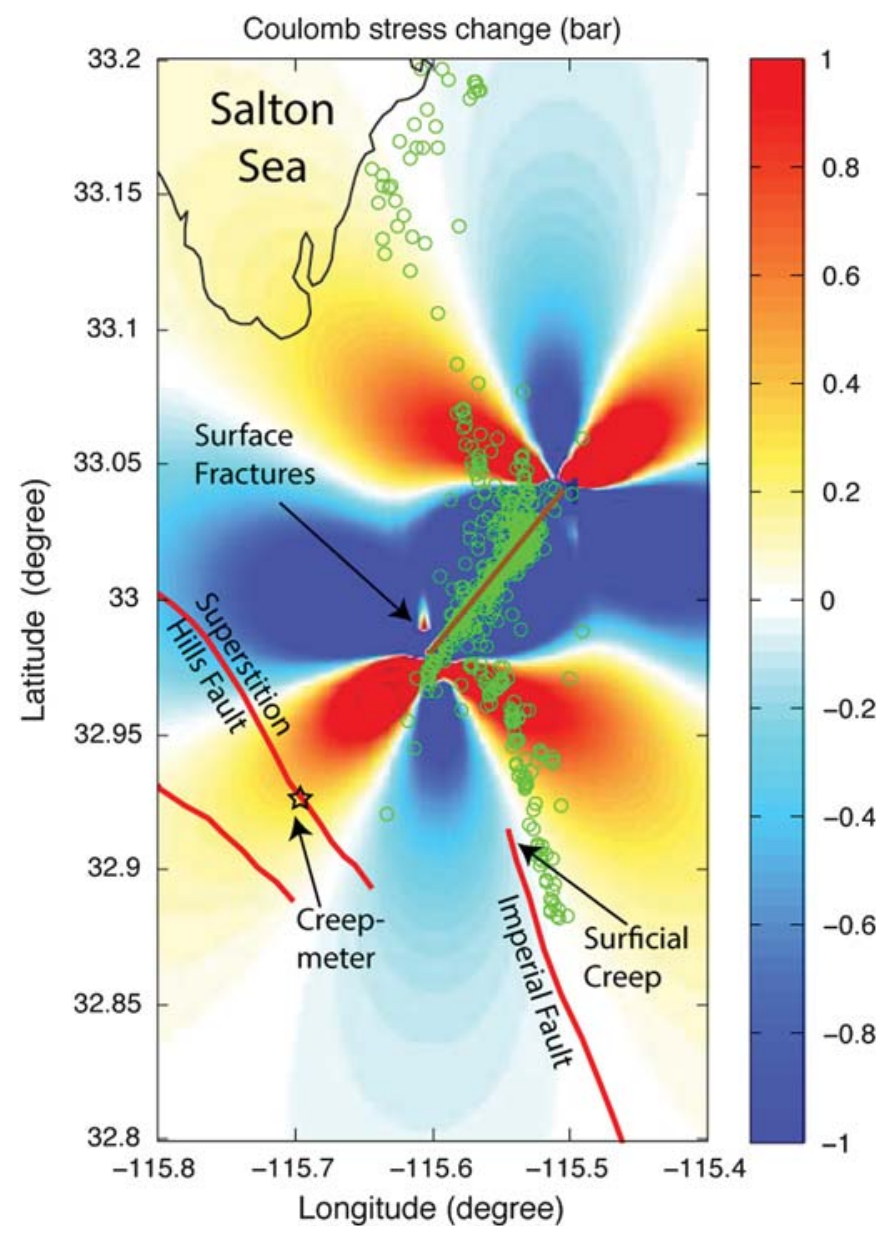

D Figure 10. Coulomb static stress change model of the $M_{\mathrm{w}} 5.4$ Brawley mainshock for optimally oriented strike-slip faults, which approximately follow the strike of the Superstition Hills fault. The brown line is the projection of the mainshock source model to the ground surface. Late Quaternary faults are shown as solid red lines. Green dots are relocated earthquakes that occurred -1 to 23 days after the mainshock. Locations of surface fractures, the creepmeter (see Fig. 9), and the surficial creep on the northern Imperial fault are also shown. accommodated the small earthquakes within the BSZ are either weaker or closer to failure than the major faults. The linear alignment of seismicity next to the Imperial fault could be reactivation of the aftershock zone of the $M_{\mathrm{w}} 6.41979$ Imperial Valley aftershock zone.

As discussed earlier, a creepmeter on the Superstition Hills fault detected two offsets of 0.1 and $0.05 \mathrm{~mm}$ during the two largest events in the sequence. Triggered slip was also reported along the Imperial fault based on InSAR and field investigations, as discussed earlier.

The slip offsets on the northern Imperial and Superstition Hills faults are qualitatively consistent with the Coulomb stress changes incremented in the earthquake. Triggered slip is typically manifested as the release of shallow strain on a surface fault as it attempts to "catch up" with deeper aseismic or seismic slip that has already developed on the fault at depths below a few kilometers. In addition, transient strains from surface waves shake surface faults loose and permit them to release this locally stored strain. Dynamic processes were involved because normally viscous processes cause moderate surface creep, and yet the triggered slip was instantaneous and showed no evidence for afterslip. The location of the creepmeter in the area of enhanced slip and the larger slip released by the earlier but smaller $M_{\mathrm{w}} 5.3$ earthquake is consistent with the dynamic release of existing strain (by transiently enhancing slip conditions in the near surface). Less slip was released in the $M_{\mathrm{w}} 5.4$ mainshock presumably because the earlier shock had already released some of the local strain near the fault.

\section{WILDLIFE LIQUEFACTION ARRAY}

The WLA (Fig. 11) is located less than $10 \mathrm{~km}$ from the Brawley swarm. This densely instrumented geotechnical field site continuously records both acceleration and pore pressure at 200 samples per second (Youd et al., 2004; Steidl and Seale, 2010). The WLA site is underlain by a $\sim 2.5$-m-thick silty-clay surface layer capping a saturated sand layer from 2.5 to $7 \mathrm{~m}$ depth before transitioning back into silty clay. Acceleration is recorded at the surface and just above, within, and below the liquefiable layer. Eight pressure transducers are distributed throughout the liquefiable layer to observe in detail the liquefaction process during earthquakes. This sequence of earthquakes provided the largest ground motions and pore pressure response since the facility became operational in 2004. An example of the data is shown in Figure 11, showing the pore pressure correlating with the vertical accelerations initially until the shear wave arrives and then quickly increasing to an excess pore pressure ratio, $R_{\mathrm{u}}$, of over $60 \%$. The excess pore pressure ratio, $R_{\mathrm{u}}$, is a value typically expressed between $0 \%$ and $100 \%$, in which an $R_{\mathrm{u}}$ of $0 \%$ represents the normal hydrostatic pressure level, and $100 \%$ represents a pressure level equal to the lithostatic pressure at which a site is considered liquefied.

The set of observations from this swarm of earthquakes provides a unique opportunity to observe the evolution of pore pressure generation with time throughout the liquefiable layer at an unprecedented level of detail. This includes both the 
27 August 2012 M4.9 Recorded at the NEES@UCSB WLA Site

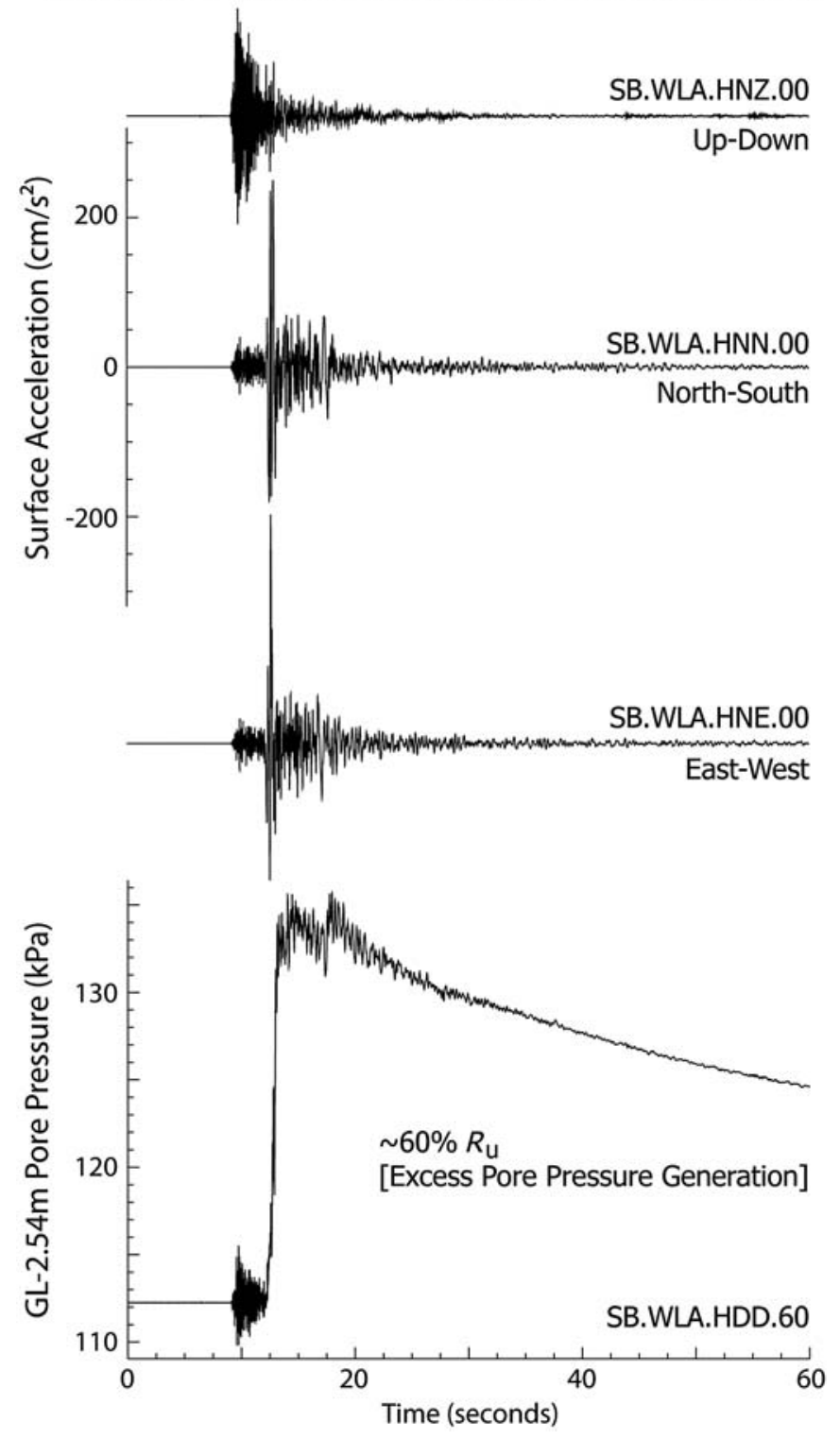

$\Delta$ Figure 11. Ground-motion and pore pressure response from the 04:41 UTC 27 August $2012 M_{\mathrm{w}} 4.9$ earthquake. The top three traces are the acceleration time histories with peak ground motions over $30 \% \mathrm{~g}$. The bottom trace is the resulting pore pressure response at $2.54 \mathrm{~m}$ depth (GL-2.54) with an excess pore pressure ratio $\left(R_{\mathrm{u}}\right)$ of $63 \%$ at the top of the liquefiable layer.

detail within the timescale of any single event, as well as the effect of multiple events occurring one after another and compounding the excess pore pressure generation or ratcheting up the system as it approaches liquefaction. The swarm more than doubled the number of observations of earthquakes at the WLA site with excess pore pressure generation, with 16 new events. These important data are providing in situ empirical evidence documenting the range of ground-motion levels at which the onset of excess pore pressure begins, augmenting the laboratory data from cyclic triaxial and centrifuge testing.

\section{SHAKEALERT PERFORMANCE}

To demonstrate the feasibility of earthquake early warning (EEW) in California, Caltech, University of California Berkeley, Swiss Federal Institute of Technology (ETH Zurich), and University of Southern California have developed and implemented the California Integrated Seismic Network (CISN) ShakeAlert Demonstration System (Böse, Allen et al., 2012). ShakeAlert combines estimates of earthquake magnitudes and locations and their uncertainties as determined by three EEW algorithms $\left(\tau_{c}-P_{d}\right.$ Onsite, Virtual Seismologist, and ElarmS) to calculate and report some seconds after the event origin the most probable earthquake source and ground-motion parameters using the currently available information. The parameters are regularly updated and displayed in real time on User Display, which is a Java application that runs on a user's desktop PC. Real-time reports are currently received by $\sim 80$ individuals and test users from critical industries and emergency response organizations in California.

During the Brawley sequence on 26 and 27 August 2012, CISN ShakeAlert detected and processed 39 out of 50 earthquakes with $M_{\mathrm{w}} \geq 3.0$; the largest missed event was $M_{\mathrm{w}} 3.9$. All events were detected within 7 to $9 \mathrm{~s}$ from event origin. The two largest events $\left(M_{\mathrm{w}} 5.4\right.$ and $\left.M_{\mathrm{w}} 5.3\right)$ were initially overestimated by $\sim 0.5$-magnitude unit; the final report overestimated the events by $\sim 0.3$ unit. It has been observed earlier that the $\tau_{c}-P_{d}$ Onsite algorithm tends to overestimate the magnitudes for earthquakes in the Imperial Valley, which seems to be caused by the general low stress drops of these events. Although no damage was expected in Los Angeles $(\sim 300 \mathrm{~km})$, the Brawley sequence demonstrated that warning times of more than $60 \mathrm{~s}$ could be provided for a large earthquake on the southern San Andreas fault at a similar distance range (such as the $M_{\mathrm{w}} 7.8$ ShakeOut scenario earthquake by Jones et al., 2008). To improve the performance of CISN ShakeAlert during large earthquakes, we are developing new algorithms for finite fault rupture and slip detection, including the usage of high-rate real-time GPS data (Böse, Heaton et al., 2012).

\section{DISCUSSION}

The Brawley swarm took place within the Salton Trough (Imperial Valley), a sediment-filled basin characterized by transtensional tectonics, high heat flow (Lachenbruch et al., 1985), and local volcanism as young as Holocene in age (Schmitt et al., 2013). New crustal area is created by processes of magmatic underplating and intrusion, sedimentation, and metamorphism as the Pacific and North America plates slide obliquely apart (Fuis et al., 1984; Schmitt and Vazquez, 2006). Lekic et al. (2011) used receiver function images of the lithosphere to infer that pure shear or steeply dipping shear zones with opposing dips accommodate crustal deformation in the Salton Trough region. The 2012 Brawley swarm is consistent with such a model, with left-lateral sense of shear on northeaststriking planes, which complements the right-lateral motion on the major north-northwest-striking faults. Such right-lateral 
motion occurred in the $M_{\mathrm{w}} 6.41979$ Imperial Valley earthquake. In addition, seismicity that occurred during the Brawley swarm was induced by a transtensional static stress change, extending approximately $20 \mathrm{~km}$ to the south across the Mesquite basin and approximately $15 \mathrm{~km}$ to Westmoreland in the north. Thus, the 2012 swarm activated the BSZ along its whole length, although all of the events were small $\left(M_{\mathrm{w}}<3\right)$. Further north, within the Salton Sea, the seismicity patterns are more suggestive of bookshelf faulting (Hauksson et al., 2012).

The nearest major faults with recognized Quaternary surface rupture, in the vicinity of the 2012 Brawley swarm, are the Imperial and Brawley faults to the south, faults underwater in the Salton Sea to the north (Jennings and Bryant, 2010), and the Superstition Hills and Superstition Mountain faults to the west. Nevertheless, alignments of earthquakes from previous swarms (Shearer et al., 2005; Lin et al., 2007; Lohman and McGuire, 2007), fumarolic vents (Lynch and Hudnut, 2008), and faults displacing sedimentary layers in and around the southern Salton Sea (Brothers et al., 2009; Rymer et al., 2011) suggest that the modern deformation is controlled by a complex set of intersecting northeast-, north-, and northwesttrending faults whose surface expression has been masked by agricultural activity and repeated basin flooding events.

The thickness of sedimentary layers in this region is as much as $5 \mathrm{~km}$ (Fuis et al., 1984) due to the ongoing plate boundary subsidence and periodic infilling with sediments of the Colorado River and/or the Gulf of California. Some of the sedimentary rocks lower in the section have been metamorphosed (greenschist facies; Fuis et al., 1984) by the extremely high temperatures at moderate depth. The focal depths of the hypocenters range from 4 to $9 \mathrm{~km}$, with the largest events in the depth range of $5-7 \mathrm{~km}$. Thus, this sequence appears to have taken place very close to the base of the basin sediments where brittle rupture is probably facilitated by induration of the basement. The presence of a possible surface rupture and InSAR-detected crustal deformation also suggest that the sequence was very shallow. The Brawley geothermal area at the northeast end of the swarm may benefit from permeability maintained by ongoing seismicity at depth. Because the most recent chapter in anthropogenic activity here only goes back a few years, this geothermal area does not have the steady decades-long seismic signature observed in geothermal areas located at the south end of the Salton Sea.

The $2010 M_{\mathrm{w}} 7.2$ El Mayor-Cucapah earthquake sequence is the most recent earthquake sequence in the general vicinity (Hauksson et al., 2011). It started with a mainshock epicenter located approximately $100 \mathrm{~km}$ to the southsoutheast. The aftershocks crossed the Mexico-United States border, and the triggered seismicity was recorded along the Elsinore and San Jacinto faults, including in the BSZ. The static stress changes from the 2010 mainshock may have increased stress on faults in the BSZ. The large geographical reach of the 2010 mainshock and the most recent swarm activity in the BSZ suggest that a much larger region has become seismically active than was the case prior to the 1979 earthquake.

\section{CONCLUSIONS}

Like many other swarms recorded in the BSZ in the twentieth century, the 2012 Brawley swarm exhibited a high rate of activity, with several earthquakes near the magnitude of the largest event of $M_{\mathrm{w}}$ 5.4. The high rate of seismic activity lasted approximately $12 \mathrm{hr}$, followed by a lower rate extending for weeks. This seismicity reactivated the northernmost part of the aftershock zone of the $1979 M_{\mathrm{w}} 6.4$ Imperial Valley earthquake. It also triggered a lesser amount of activity extending approximately another $20 \mathrm{~km}$ to the south and $10 \mathrm{~km}$ to the north. Most of the events exhibited strike-slip faulting with northeast- or northwest-striking nodal planes; only a few events with normal faulting were recorded.

Several lineations are visible in the earthquake distribution, with the most prominent being a $10-\mathrm{km}$-long southweststriking feature, consistent with one of the nodal planes of the mainshock, as well as with event focal depths in the range 4-9 km. Very minor surface faulting or fracturing in the epicentral region, near the southwest end of the seismicity zone, accompanied the swarm. The surface deformation was located with the special aid of high-resolution InSAR and documented by field investigation. The timing of this surface slip is unclear, but it could be either coseismic or afterslip. Also, minor creep was observed on the northern Imperial fault and the Superstition Hills fault. The WLA recorded both strong-motion and pore pressure data, indicating that a saturated soil layer at a few meters depth was strained $50 \%$ toward liquefaction. The swarm provided valuable real-time test data for the evolving ShakeAlert system. $\mathbf{<}$

\section{ACKNOWLEDGMENTS}

We thank the personnel of the United States Geological Survey (USGS)-California Institute of Technology (Caltech) Southern California Seismic Network (SCSN) for picking the arrival times and archiving the seismograms and the Southern California Earthquake Data Center for distributing the data. TerraSAR-X data are copyright 2012 DLR and were provided under the Group on Earth Observation (GEO) Geohazard Supersite program project prlund_GEO0927. E. Hauksson and W. Yang were supported by the National Earthquake Hazards Reduction Program/USGS Grant 12HQPA0001. This research was also supported by the Southern California Earthquake Center (SCEC), which is funded by National Science Foundation (NSF) Cooperative Agreement EAR0529922 and USGS Cooperative Agreement 07HQAG0008. This paper is Contribution 1678 of SCEC and Contribution 10083 of the Division of Geological and Planetary Sciences, Caltech, Pasadena, California.

We thank K. Marty (Imperial Valley College) and S. Williams (consulting geologist from Imperial, California) for help with fieldwork. The high-rate GPS data were processed and provided by S. Owen from the Jet Propulsion Laboratory (JPL). Part of this research was supported by the National Aeronautics and Space Administration (NASA) Earth Surface 
and Interior focus area and performed at the JPL, Caltech. We thank G. Fuis and D. Hill for reviews and J. Hole for valuable discussions about the tectonics and velocity structure. J. Stock's participation was supported by NSF Grant OCE-0742253.

The University of California at Santa Barbara operates the Wildlife Liquefaction Array facility, with funding through the George E. Brown, Jr., Network for Earthquake Engineering Simulation program of the NSF under Award CMMI0927178. Most figures were done using GMT (Wessel and Smith, 1998).

\section{REFERENCES}

Bilham, R., N. Suszek, and S. Pinkney (2004). California creepmeters, Seismol. Res. Lett. 75, no. 4, 481-492.

Bodin, P., R. Bilham, J. Behr, J. Gomberg, and K. Hudnut (1994). Slip triggered on southern California faults by the Landers, earthquake sequence, Bull. Seismol. Soc. Am. 84,, no. 3, 806-816.

Böse, M., R. Allen, H. Brown, G. Cua, M. Fischer, E. Hauksson, T. Heaton, M. Hellweg, M. Liukis, D. Neuhauser, P. Maechling, and CISN EEW Group (2012). CISN ShakeAlert-development of a prototype earthquake early warning system for California, in Early Warning for Geological Disasters-Scientific Concepts and Current Practice F. Wenzel and J. Zschau (Editors), Springer (in press).

Böse, M., T. H. Heaton, and E. Hauksson (2012). Real-time finite fault rupture detector (FinDer) for large earthquakes, Geophys. J. Int. 191, no. 2, 803-812, doi: 10.1111/j.1365-246X.2012.05657.x.

Brothers, D. S., N. Driscoll, G. Kent, A. Harding, J. M. Babcock, and R. L. Baskin (2009). Tectonic evolution of the Salton Sea inferred from seismic reflection data, Nature Geosci. 2, 581-584.

Chen, X., and P. M. Shearer (2011). Comprehensive analysis of earthquake source spectra and swarms in the Salton Trough, California, J. Geophys. Res. 116, B09309, doi: 10.1029/2011JB008263.

Chu, R., and D. V. Helmberger (2013). Source parameters of the shallow 2012 Brawley earthquake, Imperial Valley, Bull. Seismol. Soc. Am. 103, no. 2a, doi: 10.1785/0120120324 (in press).

Clinton, J. F., E. Hauksson, and K. Solanki (2006). An evaluation of the SCSN moment tensor solutions: robustness of the $M_{\mathrm{w}}$ magnitude scale, style of faulting, and automation of the method, Bull. Seismol. Soc. Am. 96, no. 5, doi: 10.1785/0120050241.

Dreger, D. S., and D. V. Helmberger (1993). Determination of source parameters at regional distances with three-component sparse network data, J. Geophys. Res. 98, 8107-8125.

Fuis, G. S., W. D. Mooney, J. H. Healy, G. A. McMechan, and W. J. Lutter (1984). A seismic refraction survey of the Imperial Valley region, California, J. Geophys. Res. 89, 1165-1189.

Han, L., J. A. Hole, J. M. Stock, G. S. Fuis, N. W. Driscoll, A. M. Kell, G. Kent, and A. J. Harding (2012). Active rifting processes in the central Salton Trough, California, constrained by the Salton Seismic Imaging Project (SSIP) Abstract T51B-2590, Presented at 2012 Fall Meeting, $A G U$, San Francisco, California, 3-7 December.

Hardebeck, J. L., and P. M. Shearer (2002). A new method for determining first-motion focal mechanisms, Bull. Seismol. Soc. Am. 92, 2264.

Hardebeck, J. L., and P. M. Shearer (2003). Using $S / P$ amplitude ratios to constrain the focal mechanisms of small earthquakes, Bull. Seismol. Soc. Am. 93, 2434-2444.

Hauksson, E. (2000). Crustal structure and seismicity distributions adjacent to the Pacific and North America plate boundary in southern California, J. Geophys. Res. 105, no. 13, 875-903.

Hauksson, E., J. Stock, K. Hutton, W. Yang, A. Vidal, and H. Kanamori (2011). The $2010 M_{\mathrm{w}}$ 7.2 El Mayor-Cucapah earthquake sequence, Baja California, Mexico and southernmost California, USA: active seismotectonics along the Mexican Pacific Margin, Pure Appl. Geophys. 168, 1255-1277, doi: 10.1007/s00024-010-0209-7.
Hauksson, E., W. Yang, and P. M. Shearer (2012). Waveform relocated earthquake catalog for southern California (1981 to June 2011), Bull. Seismol. Soc. Am. 102, no. 5, doi: 10.1785/0120120010.

Hudnut, K. W., L. Seeber, and J. Pacheco (1989). Cross-fault triggering in the November 1987 Superstition Hills earthquake sequence, southern California, Geophys. Res. Lett. 16, no. 2, 199-202.

Hutton, L. K., J. Woessner, and E. Hauksson (2010). Seventy-seven years (1932-2009) of earthquake monitoring in southern California, Bull. Seismol. Soc. Am. 100, no. 2, 423-446, doi: 10.1785/ 0120090130.

Jennings, C. W., and W. A. Bryant (2010). 2010 Fault activity map of California, Geologic Data Map No. 6, California Geological Survey, Sacramento, California, Scale 1:750,000.

Ji, C., D. J. Wald, and D. V. Helmberger (2002). Source description of the 1999 Hector Mine, California, earthquake, part I: wavelet domain inversion theory and resolution analysis, Bull. Seismol. Soc. Am. 92, no. 4, 1192-1207.

Johnson, C. E., and D. P. Hill (1982). Seismicity of the Imperial Valley, in The Imperial Valley, California, earthquake of October 15, 1979, C. E. Johnson, C. Rojahn, and R. V. Sharp (Editors), U.S. Geol. Surv. Profess. Pap. 1254, 15-24.

Johnson, C. E., and L. K. Hutton (1982). Aftershocks and preearthquake seismcity, in The Imperial Valley, California, earthquake of October 15, 1979, C. E. Johnson, C. Rojahn, and R. V. Sharp (Editors), U.S. Geol. Surv. Profess. Pap. 1254, 59-76.

Jones, L. M., R. Bernknopf, D. Cox, J. Goltz, K. Hudnut, D. Mileti, S. Perry, D. Ponti, K. Porter, M. Reichle, H. Seligson, K. Shoaf, J. Treiman, and A. Wein (2008), The ShakeOut Scenario, U.S. Geological Survey Open-File Report 2008-1150 and California Geological Survey Preliminary Report 25, http://pubs.usgs.gov/of/2008/1150/

Kanamori, H., and L. Rivera (2008). Source inversion of $W$ phase: speeding up seismic tsunami warning, Geophys. J. Int. 175, no. 1, 222-238, doi: 10.1111/j.1365-246X.2008.03887.x.

Kisslinger, C., and L. M. Jones (1991). Properties of aftershock sequences in southern California, J. Geophys. Res. 96, no. B7, 11,947-11,958, doi: 10.1029/91JB01200.

Lachenbruch, A. H., J. H. Sass, and S. P. Galanis (1985). Heat flow in southernmost California and the origin of the Salton Trough, J. Geophys. Res. 90, 6709-6736.

Larsen, S., and R. Reilinger (1991). Age constraints for the present fault configuration in the Imperial Valley, California: evidence for northwestward propagation of the Gulf of California rift system, J. Geophys. Res. 96, no. B6, 10,339-10,346.

Lekic, V., S. W. French, and K. M. Fischer (2011). Lithospheric thinning beneath rifted regions of southern California, Science 334, no. 6057, 783-787, doi: 10.1126/science.1208898.

Lin, G., P. M. Shearer, E. Hauksson, and C. H. Thurber (2007). A threedimensional crustal seismic velocity model for southern California from a composite event method, J. Geophys. Res. 112, B11306, doi: $10.1029 / 2007 J B 004977$.

Lin, J., and R. S. Stein (2004). Stress triggering in thrust and subduction earthquakes, and stress interaction between the southern San Andreas and nearby thrust and strike-slip faults, J. Geophys. Res. 109, no. B02303, doi: 10.1029/2003JB002607.

Lohman, R., and J. McGuire (2007). Earthquake swarms driven by aseismic creep in the Salton Trough, California, J. Geophys. Res. 112, B04405, doi: 10.1029/2006JB004596.

Lynch, D. K., and K. W. Hudnut (2008). The Wister mud pot lineament: southeastward extension or abandoned strand of the San Andreas fault? Bull. Seismol. Soc. Am. 98, 1720-1729.

Reasenberg, P. A., and L. M. Jones (1989). Earthquake hazard after a mainshock in California, Science 243, 1173-1176.

Rose, E. J., G. S. Fuis, J. M. Stock, J. A. Hole, A. M. Kell, G. Kent, N. W. Driscoll, M. Goldman, A. M. Reusch, L. Han, R. R. Sickler, R. D. Catchings, M. J. Rymer, C. J. Criley, S. M. Skinner, C. J. SlaydayCriley, J. M. Murphy, E. J. Jensen, R. McClearn, A. J. Ferguson, L. A. Butcher, M. A. Gardner, J. R. Svitek, J. A. Cotton, D. S. Croker, 
A. J. Harding, J. M. Babcock, S. Harder, and C. Rosa (2012). Report for borehole explosion and air-gun data acquired in the 2011 Salton Seismic Imaging Project (SSIP), southern California: description of the survey, U.S. Geol. Surv. Open-File Rept. 7 (in review).

Rosen, P. A., S. Hensley, G. Peltzer, and M. Simons (2004). Updated repeat orbit interferometry package released, Eos Trans. $A G U$ 85, 47.

Rymer, M. J., J. A. Treiman, K. J. Kendrick, J. J. Lienkaemper, R. J. Weldon, R. Bilham, M. Wei, E. J. Fielding, J. L. Hernandez, B. P. E. Olson, P. J. Irvine, N. Knepprath, R. R. Sickler, X. Tong, and M. E. Siem (2011). Triggered surface slips in southern California associated with the 2010 El Mayor-Cucapah, Baja California, Mexico, U.S. Geol. Surv. Open-File Rept. 2010-1333 and Calif. Geol. Surv. Spec. Rept. 221, 62 pp., available at http:// pubs.usgs.gov/of/2010/1333/ (last accessed January 2013).

Schmitt, A. K., and J. Vazquez (2006). Alteration and remelting of nascent oceanic crust during continental rupture: evidence from zircon geochemistry of rhyolites and xenoliths from the Salton Trough, California, Earth Planet. Sci. Lett. 252, 260-274.

Schmitt, A. K., A. Martín, D. F. Stockli, K. A. Farley, and O. M. Lovera (2013). (U-Th)/He zircon and archaeological ages for a late prehistoric eruption in the Salton Trough (California, USA), Geology 41, 7-10, doi: 10.1130/G33634.1.

Scholz, C. H. (1968). The frequency-magnitude relation of microfracturing in rock and its relation to earthquakes, Bull. Seismol. Soc. Am. 58, 399-415.

Sharp, R. V., K. E. Budding, J. Boatwright, M. J. Ader, M. G. Bonilla, M. M. Clark, T. E. Fumal, K. K. Harms, J. J. Lienkaemper, D. M. Morton, B. J. O’Neill, C. L. Ostergren, D. J. Ponti, M. J. Rymer, J. L. Saxton, and J. D. Sims (1989). Surface faulting along the Superstition Hills fault zone and nearby faults associated with the earthquakes of 24 November 1987, Bull. Seismol. Soc. Am. 79, 252-282.

Shearer, P., E. Hauksson, and G. Lin (2005). Southern California Hypocenter Relocation with Waveform Cross-Correlation: Part 2. Results Using Source-Specific Station Terms and Cluster Analysis, Bull. Seismol. Soc. Am. 95, 904-915.

Shearer, P. M., G. A. Prieto, and E. Hauksson (2006). Comprehensive analysis of earthquake source spectra in southern California, J. Geophys. Res. 111, B06303, doi: 10.1029/2005JB003979.

Steidl, J. H., and S. Seale (2010). Observations and analysis of ground motion and pore pressure at the NEES instrumented geotechnical field sites, in Proc. of the 5th Int. Conf. on Recent Advances in Geotechnical Earthquake Engineering and Soil Dynamics, San Diego, California, 24-29 May 2010, paper no. 133b, ISBN-887009-15-9.

Suárez-Vidal, F., L. Munguía-Orozco, M. González-Escobar, J. GonzálezGarcía, and E. Glowacka (2007). Surface rupture of the Morelia fault near the Cerro Prieto geothermal field, Mexicali, Baja California, Mexico, during the $M_{\mathrm{w}} 5.4$ earthquake of 24 May 2006, Seismol. Res. Lett. 78, 394-403.

Toda, S., R. S. Stein, K. Richards-Dinger, and S. Bozkurt (2005). Forecasting the evolution of seismicity in southern California: animations built on earthquake stress transfer, J. Geophys. Res. no. B05S16, doi: 10.1029/2004JB003415.

Utsu, T. (1961). A statistical study on the occurrence of aftershocks, Geophysical Geophys. Mag. 30, 521-605.

Waldhauser, F., and W. L. Ellsworth (2000). A double-difference earthquake location algorithm: method and application to the Northern Hayward fault, California, Bull. Seismol. Soc. Am. 90, 1353-1368.

Wessel, P., and W. H. F. Smith (1998). New version of the generic mapping tools released, Eos Trans. $A G U$ 79, 579.

Wiemer, S. (2001). A software package to analyze seismicity: ZMAP, Seismol. Res. Lett. 72, 373-382.

Youd, T. L., J. H. Steidl, and R. L. Nigbor (2004). Lessons learned and the need for instrumented liquefaction sites, Soil Dyn. Earthquake Eng. 24, no. 9-10, 639-646.
Zhao, L. S., and D. V. Helmberger (1994). Source estimation from broadband regional seismograms, Bull. Seismol. Soc. Am. 84, no. 1,91-104.

Zhu, L., and D. V. Helmberger (1996). Advancement in source estimation techniques using broadband regional seismograms, Bull. Seismol. Soc. Am. 86, no. 5, 1634-1641.

Zhu, L., and L. A. Rivera (2002). A note on dynamic and static displacements from a point source in multilayered media, Geophys. J. Int. 148, 619-627.

Egill Hauksson
Joann Stock
Maren Boese
John Galetzka
Kate Hutton
Hiroo Kanamori
Shengji Wei
Wenzheng Yang
California Institute of Technology
1200 East California Blvd.
Pasadena, California 91125 U.S.A.
hauksson@caltech.edu
Roger Bilham
University of Colorado
Campus Box 399
Department of Geological Sciences
Complo399 U.S.A.

Xiaowei Chen

Peter M. Shearer

Institute of Geophysics and Planetary Physics 0225

University of California San Diego

La Jolla, California 92093-0225 U.S.A.

Eric J. Fielding

Jet Propulsion Laboratory

California Institute of Technology

4800 Oak Grove Drive

Pasadena, California 91109 U.S.A.

Kenneth W. Hudnut

Lucile M. Jones

United States Geological Survey

525 South Wilson Avenue

Pasadena, California 91106 U.S.A.

Jamie Steidl

University of California Santa Barbara

Earth Research Institute

Santa Barbara, California 93106-1100 U.S.A.

Jerry Treiman

California Geological Survey

888 South Figueroa Street, Suite 475

Los Angeles, California 90017 U.S.A. 